\title{
Removal of $\mathrm{Eu}^{3+}, \mathrm{Ce}^{3+}, \mathrm{Sr}^{2+}$ and $\mathrm{Cs}^{+}$ions from radioactive waste solutions by modified activated carbon prepared from coconut shells
}

\author{
H. Moloukhia ${ }^{a}$, W. S. Hegazy ${ }^{b}$, E. A. Abdel-Galil ${ }^{a, *}$ and S.S. Mahrous ${ }^{a}$ \\ ${ }^{a}$ Environmental Radioactive Pollution Department, Hot Laboratories Center, Atomic Energy \\ Authority, P.O. Box 13759,Cairo, Egypt. \\ ${ }^{b}$ Chemistry Department, Faculty of Women, Ain Shams university, Heliopolis,cairo.Egypt.
}

\section{Abstract}

The modified surface of activated carbon (MSAC) was prepared from the agricultural byproduct coconut shells, by physical and chemical activation processes, and it was tested for the treatment of simulated radioactive waste solutions included some metal ions, namely Europium, Cerium, Strontium, and Cesium. The structural morphology and composition of the modified surface activated carbon coconut shells (MSAC) were evaluated by SEM, XRD, FTIR, XRF, and elemental analysis. The solubility experiments show that the prepared sorbent (MSAC) has reasonably good chemical stability. The influence of solution $\mathrm{pH}$, contact time, adsorbent dosage, adsorption temperature, initial metal ion concentration and interfering substances such as sodium chloride salt and ethylenediaminetetraacetic acid (EDTA), on the adsorption performance of $\mathrm{Eu}^{3+}, \mathrm{Ce}^{3+}, \mathrm{Sr}^{2+}$ and $\mathrm{Cs}^{+}$ions on to the prepared sorbent (MSAC) were examined by batch technique. The saturation capacity of the MSAC for the studied metal ions was found to be very high as compared to the break-through capacity, and it was found to be $136.84,85.55,69.85$ and $60.00 \mathrm{mg} \mathrm{g}^{-1}$ for $\mathrm{Eu}^{3+}, \mathrm{Ce}^{3+}, \mathrm{Sr}^{2+}$ ,and $\mathrm{Cs}^{+}$ions, respectively. Using the Van't Hoff linear plot, the thermodynamic parameters, $\Delta H^{\circ}, \Delta S^{\circ}$, and $\Delta G^{\circ}$ were also evaluated. . Results show that studied sorbent (MSAC) is efficient to remove more than 98.43, 90.7, 38.65, and 37.4\%, of $\mathrm{Eu}^{3+,} \mathrm{Ce}^{3+,} \mathrm{Sr}^{2+}$ and $\mathrm{Cs}^{+}$ions respectively, at 180 min equilibrium time. The developed sorbent is considered as a good replacement technology for removal of $\mathrm{Eu}^{3+}, \mathrm{Ce}^{3+}, \mathrm{Sr}^{2+}$, and $\mathrm{Cs}^{+}$ions from radioactive waste solutions due to its low-cost, good efficiency, high saturation capacity, as well as easy handling with no or small amount of secondary sludge.

Keywords: Coconut shells; Modified activated carbon Adsorption; Radionuclides; Waste solutions; Thermodynamic parameters.

Corresponding author. Tel.: +20 1159895618, Fax 20 244620784, Cairo, Egypt. E-mail address: ezzat 20010@yahoo.com 


\section{Introduction}

The nuclear industry generates considerable amounts of waste, which may require further treatment before safe disposal. Low and intermediate level wastes are generated in nuclear fuel cycle operations, in the production of radioisotopes for medical, industrial purposes and in nuclear research centers. These types of wastes are characterized by low level activity and relatively large volume (IAEA,1970). Radionuclides existing in the low and intermediate level liquid radioactive waste are generally classified into two types first: activated corrosion products and transition metals such as $\mathrm{Ni}$, Co, etc. Second: fission products such as., ${ }^{137} \mathrm{Cs},{ }^{90} \mathrm{Sr}$, ...etc. Moreover, cobalt $\left({ }^{58} \mathrm{Co}\right.$ and $\left.{ }^{60} \mathrm{Co}\right)$ and cesium $\left({ }^{134} \mathrm{Cs}\right.$ and $\left.{ }^{137} \mathrm{Cs}\right)$ are major radioisotopes because of their relatively long half - live and high concentration in the liquid radioactive waste. Aqueous radioactive wastes represent the main volume to be treated. The processes used for the treatment of aqueous radioactive waste are based on chemical precipitation ( Jantzen ,2004; Abdel-Rahman et al.2011), ion exchange

( El-Naggar et al.2005; El-Aryan et al.2014), adsorption ( Abdalla and Moloukhia 2006; Moloukhia et al .2006), and solvent extraction (Awwad et al.2005; Nowier et al .2005). All these methods have been found to be expensive and may not be suitable for developing countries. Therefore, there is needed to look for alternatives to investigate a low-cost method which is effective and economic. Adsorption is a good proposal for high strength and low volume of wastewater. Adsorption is an effective purification and separation technique used in industry especially in water and wastewater treatment (Nandal et al .2014).

The present work aims to study the ability of the modified surface activated carbon prepared from coconut shells (MSAC) to remove the investigated metal ions from simulated radioactive waste, (ii) elaborate the parameters affecting the sorption process and (iii) evaluate the saturation capacity and the thermodynamic parameters of the sorption process.

\section{Methods and Materials}

\subsection{Preparation of high quality modified activated carbon from coconut shells.}

\section{A-Preparation of activated carbon from coconut shells}

The coconut shells are washed with water to remove sticking and lose matter and then sundried for 5 days. The dried samples are then hammer -broken to pieces and converted to a powder using a mixer. Two- step procedures are followed where the prepared activated carbon is applied by mixing $40 \mathrm{gm}$. of coconut shells with $50 \mathrm{ml}$ of $\mathrm{H}_{3} \mathrm{PO}_{4}$ solution (20\%) for $24 \mathrm{hrs}$.

\section{B- Carbonization}

The paste produced was heated slowly with a heating rate of $50^{\circ} \mathrm{C} / 5 \mathrm{~min}$ and kept for $3 \mathrm{hrs}$ at $500^{\circ} \mathrm{C}$ in a muffle furnace. The cooled mass is washed thoroughly with distilled water until neutral $\mathrm{pH}$, then dried at $110^{\circ} \mathrm{C}$ (Daifullah and moloukhia, 2002).

\section{C-Surface modification process}

Multiple chemical activation and heating is performed for the prepared activated carbon as follows: 
The prepared activated carbon was mixed with $\mathrm{H}_{2} \mathrm{O}_{2}(4 \mathrm{M})$ at room temperature until there were no gases evolved. The produced mass was washed thoroughly with distilled water and dried at $110^{\circ} \mathrm{C}$. After cooling the produced mass followed by further oxidation with $\mathrm{HNO}_{3}(6 \mathrm{M})$, with 2 hrs shaking at $80^{\circ} \mathrm{C}$. The produced high quality modified surface activated carbon was washed with distilled water to neutral $\mathrm{pH}$ and dried in oven at $110^{\circ} \mathrm{C}$ for $24 \mathrm{hrs}$ and stored in a desiccator over silica gel for later use.

\subsection{Batch adsorption studies}

Experimental conditions for studying the effect of solution $\mathrm{pH}$, contact time, adsorbent dosage, initial ion concentrations, and interfering ions such as sodium chloride salt and ethylenediaminetetraacetic acid (EDTA) were performed. For each experimental run, $0.05 \mathrm{~g}$ of MSAC was shaken at room temperature with $5 \mathrm{ml}$ of $\mathrm{Eu}^{3+}, \mathrm{Ce}^{3+}, \mathrm{Sr}^{2+}$, and $\mathrm{Cs}^{+}$metal ions solution at the speed of $400 \mathrm{rpm}$ for $5 \mathrm{hrs}$., at time intervals of $5,10,15, \ldots 60$ minutes. For the saturation capacity evaluation, repeated batch equilibration of $800 \mathrm{mg} / \mathrm{l}$ metal nitrate solutions $\left(\mathrm{Eu}^{3+}, \mathrm{Ce}^{3+}, \mathrm{Sr}^{2+}, \mathrm{and} \mathrm{Cs}^{+}\right)$ with the solid material in $\mathrm{V} / \mathrm{m}$ ratio $100 \mathrm{ml} / \mathrm{g}$ was carried out. The mixture was shaked in a shaker thermostat at $25 \pm 1 \circ \mathrm{C}$ at the speed of $400 \mathrm{rpm}$. The adsorption temperature effect is investiged on the prepared sorbent (MSAC) at 25,45 , and $65 \pm 1^{\circ} \mathrm{C}$. After equilibrium, the solid was separated and the concentration of the metal ions was measured instrumentally using Hitachi model Z-6100 atomic absorption spectrophotometer. All tests were repeated for three times and the total experimental percentage error was about $\pm 3 \%$. The following equations are applied ( Moloukhia et al 2006)

The percentage uptake $(\mathrm{U} \%)$ and distribution coefficient $\left(\mathrm{K}_{\mathrm{d}}\right)$ are calculated using the following equations:

$$
\begin{aligned}
& \mathrm{U}(\%)=\frac{C_{i}-C_{f}}{C_{i}} x 100 \\
& \left(\mathrm{~K}_{\mathrm{d}}\right)=\frac{\left[C_{i}-C_{f}\right]}{C_{f}} x \mathrm{~V} / \mathrm{m} \quad \mathrm{ml} / \mathrm{g}
\end{aligned}
$$

The apparent sorption capacity of the sorbent may be expressed in terms of the following equation:

aap

$$
\mathrm{mg} / \mathrm{g}
$$

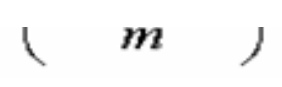

Where $C_{i}$ and $C_{f}$ are the concentrations of the ions in solution before and after equilibration, respectively, $\mathrm{V}$ is the solution volume $(\mathrm{ml})$ and $\mathrm{m}$ is the sorbent mass $(\mathrm{g})$.

\subsection{Break-through capacity}

Chromatographic column breakthrough investigations are conducted as follows. One gm of the prepared sorbent (MSAC) of particle size $<100 \mu \mathrm{m}$ is packed in a glass column $(1.4 \mathrm{~cm}$ diameter and $5 \mathrm{~cm}$ height) to give a bed height of $2.2 \mathrm{~cm}^{3}$ volume. $395 \mathrm{ml}$ of the desired neutral solutions $\left(\mathrm{pH}=5.56\right.$ (containing $100 \mathrm{mg} / \mathrm{l}$ of metal nitrate $\left[\mathrm{M}\left(\mathrm{NO}_{3}\right)_{\mathrm{x}}\right.$ where $\mathrm{M}=\mathrm{Eu}^{3+}$, 
$\mathrm{Ce}^{3+}, \mathrm{Sr}^{2+}$, and $\left.\mathrm{Cs}^{+}\right]$are passed through the column beds at a flow rate of 6-7 drops/min.Equal fractions are collected and the concentrations are continuously measured (using atomic absorption spectrophotometer $(A A S)$ and inductive coupled plasma spectrophotometer (ICPs).

The values of breakthrough capacity under the experimental conditions can be easily estimated from the following equation;

\section{Breakthrough capacity $(\mathrm{mg} / \mathrm{g})=V_{(50 \%)} x \frac{C_{0}}{m}$}

$$
\mathrm{mg} / \mathrm{g}
$$

Where,

$\mathrm{V}_{(50 \%)}$ is the effluent volume at $50 \%$ breakthrough ( $\left.\mathrm{ml}\right)$.

$\mathrm{C}_{\mathrm{o}}$ is the concentration of feed solution.

$\mathrm{m}$ is the amount of the column bed in gram .

\section{RESULTS AND DISCUSSION}

\subsection{Characterization of the obtained material (MSAC)}

\subsubsection{The physico-chemical characterization and the elemental analyses}

The physico-chemical characterization and the elemental analyses of the studied sorbent (MSAC) are shown in Table (1) and (2), respectively

Table 1. Physico-chemical characteristics of the modified activated carbon coconut shells

\begin{tabular}{|l|c|}
\cline { 2 - 2 } Parameter & Values \\
\hline Moisture content $(\%)$ & 8.00 \\
Packed density $(\mathrm{g} / \mathrm{ml})$ & 0.56 \\
Apparent density $(\mathrm{g} / \mathrm{ml})$ & 0.46 \\
Surface area $\left(\mathrm{m}^{2} / \mathrm{g}\right)$ & 482 \\
Pore volume $(\mathrm{cc} / \mathrm{g})$ & 0.454 \\
Average particle size $(\mu \mathrm{m})$ & $<100$ \\
Ash content & 5.30 \\
\hline
\end{tabular}


Table 2. Elemental analyses of the modified activated carbon coconut shells.

\begin{tabular}{|c|c|}
\hline Component & Percentage (\%) \\
\hline $\mathrm{C}$ & 68.4 \\
$\mathrm{H}$ & 2.8 \\
$\mathrm{~N}$ & 4.8 \\
$\mathrm{~S}$ & 2.10 \\
$\mathrm{P}$ & 0.5 \\
$\mathrm{SiO}_{2}$ & 7.8 \\
$\mathrm{CaO}$ & 3.38 \\
$\mathrm{Na}_{2} \mathrm{O}$ & 1.2 \\
$\mathrm{Fe}_{2} \mathrm{O}_{3}$ & 1.33 \\
$\mathrm{~K}_{2} \mathrm{O}$ & 0.82 \\
$\mathrm{P}_{2} \mathrm{O}_{5}$ & 0.66 \\
$\mathrm{MgO}$ & 0.78 \\
\hline
\end{tabular}

\subsubsection{Chemical stability}

The chemical stability of the prepared material(MSAC) was studied in water and acid $\left(\mathrm{HNO}_{3}\right.$ and $\mathrm{HCl}$ ) at different concentrations $[0.5,1,2,3,4$, and $5 \mathrm{M}]$, by mixing $100 \mathrm{mg}$ of the prepared sample with $100 \mathrm{ml}$ of the desired solution with irregular shaking for about one weak at $25 \pm 1{ }^{\circ} \mathrm{C}$. After that the filtrate is tested gravimetrically.

The solubility experiments show that the studied sorbent has reasonably good chemical stability in water and acid $\left(\mathrm{HNO}_{3}\right.$ and $\left.\mathrm{HCl}\right)$ as shown in Table (3). The results indicate that, the material is resistant to $\mathrm{HNO}_{3}$ and $\mathrm{HCl}$ media. The chemical stability of the studied sorbent is very high as compared to other activated carbon .similar results are reported by (Kobya et al .2005; Amuda et al .2011)..

Table 3. Chemical stability of the prepared sorbent (MSAC) at different acid concentrations

\begin{tabular}{|c|c|c|c|c|c|c|c|c|c|c|c|c|}
\hline & \multicolumn{12}{|c|}{ Medium } \\
\hline & \multirow[t]{2}{*}{$\mathrm{H}_{2} \mathrm{O}$} & \multicolumn{5}{|c|}{$\mathrm{HNO}_{3}$} & \multicolumn{6}{|c|}{$\mathrm{HCl}$} \\
\hline & & 0.5 & 1 & 2 & 34 & 5 & 0.5 & 1 & 2 & 3 & 4 & $5(\mathrm{M})$ \\
\hline \multicolumn{13}{|c|}{ Solubility\% } \\
\hline \multirow[t]{2}{*}{ MSAC } & $\mathrm{BD}$ & 0.7 & 1.2 & 2. & 4.57 .1 & 9 & 0.7 & 1.0 & 2.1 & 3.2 & 6.3 & 7.90 \\
\hline & & 8 & 0 & 5 & & & 0 & 5 & 0 & 0 & 0 & \\
\hline
\end{tabular}

\section{BD; Below Detection}




\subsubsection{FTIR spectrum}

The IR spectrum of the prepared sorbent (MSAC) is shown in Figures (1).From which it could be observed that the peak at $3650 \mathrm{~cm}^{-1}$ may be due to the $-\mathrm{NH}$ asymmetric stretching of amino groups (Hassan et al. 2013). The peak at $3420 \mathrm{~cm}^{-1}$ represents the $-\mathrm{OH}$ stretching vibration of carboxylic groups (Hassan et al. 2013).The bands around 2855 and $2917 \mathrm{~cm}^{-1}$ may be due to asymmetric and symmetric $\mathrm{C}-\mathrm{H}$ stretching vibrations in the aliphatic groups $-\mathrm{CH},-\mathrm{CH}_{2}$, and $-\mathrm{CH}_{3}$ (Pradhan and sandles, 1999). The peak at $1613 \mathrm{~cm}^{-1}$ represents $C=O$ stretching vibrations of the carbonyl compounds on the surface of the biomass material (Hassan et al. 2013). . The peak at $\approx 1560 \mathrm{~cm}^{-1}$ may correspond to the bending mode of water molecules ( Rao, 1963). The peak at $\approx 1450 \mathrm{~cm}^{-1}$ may be due to the deformation vibration of the hydroxyl groups ( $\mathrm{Si}-\mathrm{OH}$ deformation vibration) (El-Naggar et al. 2014). The peak exhibited at $1350 \mathrm{~cm}^{-1}$ may represent the $\mathrm{COO}^{-}$symmetric stretching vibrations as well as the $\mathrm{C}-\mathrm{N}$ stretching vibrations (Hassan et al. 2013).. The $1123 \mathrm{~cm}^{-1}$ peak may correspond to $\mathrm{C}-\mathrm{O}$ stretching vibration and $\mathrm{O}-\mathrm{H}$ bending modes of alcoholic, phenolic, and/or carboxylic groups(Pradhan and sandles, 1999). . The peak at $1030 \mathrm{~cm}^{-1}$ is due to the presence Si-O stretching bond ( Al-Degs et al. 2006]. The band at $865 \mathrm{~cm}^{-1}$ is characteristic of out-of-plane deformation vibration of $\mathrm{C}-\mathrm{H}$ in aromatic structure (Moreno-Castilla,2000). The peak at $745 \mathrm{~cm}^{-1}$ is considered to be the bonding between $\mathrm{C}$ and $\mathrm{Si}$, or the overlapping of the $\mathrm{Si}-\mathrm{O}$ and $\mathrm{Si}-\mathrm{OH}$ (Ibrahim et al.1980; Stuart,1996 ]. The peak at $520 \mathrm{~cm}^{-1}$ represents $\mathrm{O}-\mathrm{C}-\mathrm{N}$ scissoring vibrations(Hassan et al .2013). . The FTIR spectrum gives the indication of the poly functional nature of the studied sorbent.

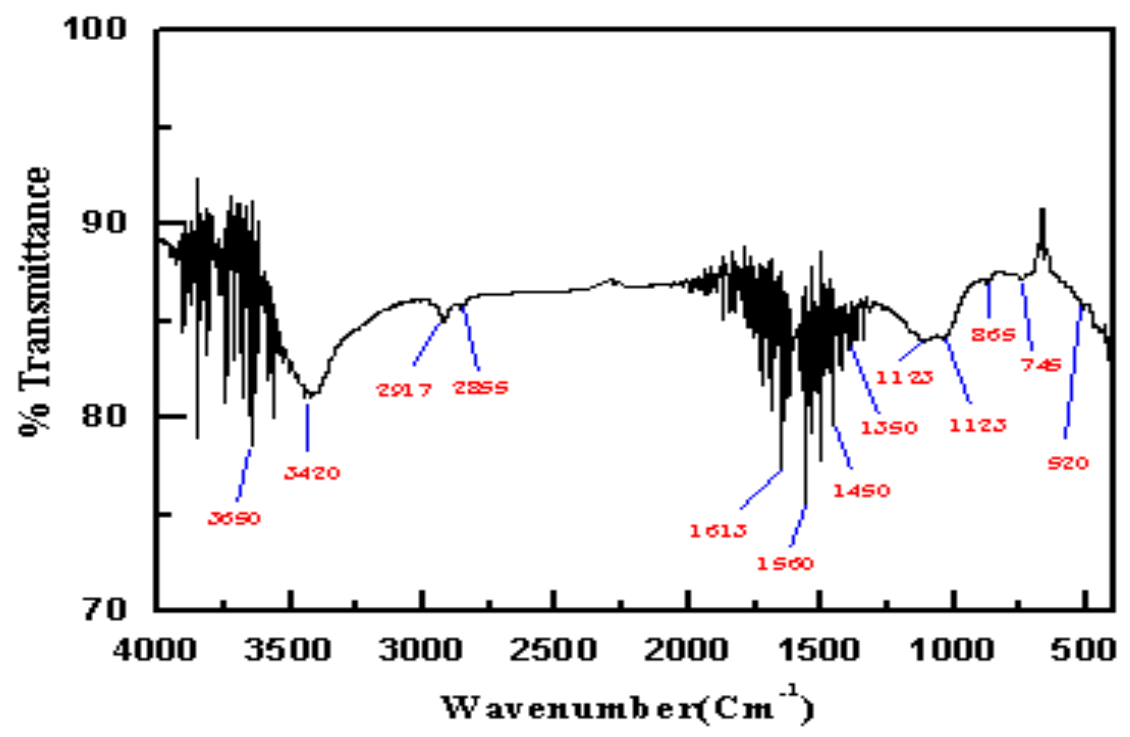

Figure 1. The IR spectrum of the modified surface activated carbon coconut shells . 


\subsubsection{TGA and DTA}

Thermogravimetric study is also carried out on prepared MSAC, up to $1000^{\circ} \mathrm{C}$ at a constant heating rate $\left(\sim 10^{\circ} \mathrm{C} \mathrm{min}^{-1}\right)$ in the atmospheric air. The TG-DT analysis data for the prepared sorbent are shown in Figure (2). The MSAC was heated from room temperature to $136.87^{\circ} \mathrm{C}$, the moisture in the sorbent was vaporized out. Similar results are reported by(Hassan et al.2013). And the total mass loss has reached $8.00 \%$. A little degradation occurred to about $395^{\circ} \mathrm{C}$ where, the total mass loss was about $1.99 \%$. It might be possible that free radical mechanism is occurred to eliminate water and to produce the volatile gases up to that temperature (Hassan et al.2013). . The hemicellulose components started to decompose between $395.81-932.71^{\circ} \mathrm{C}$ to give a loss in mass about $83.61 \%$, similar result reported by (Hassan et al.2013), from 930 to $1000^{\circ} \mathrm{C}$, the weight of the studied sorbent is constant.

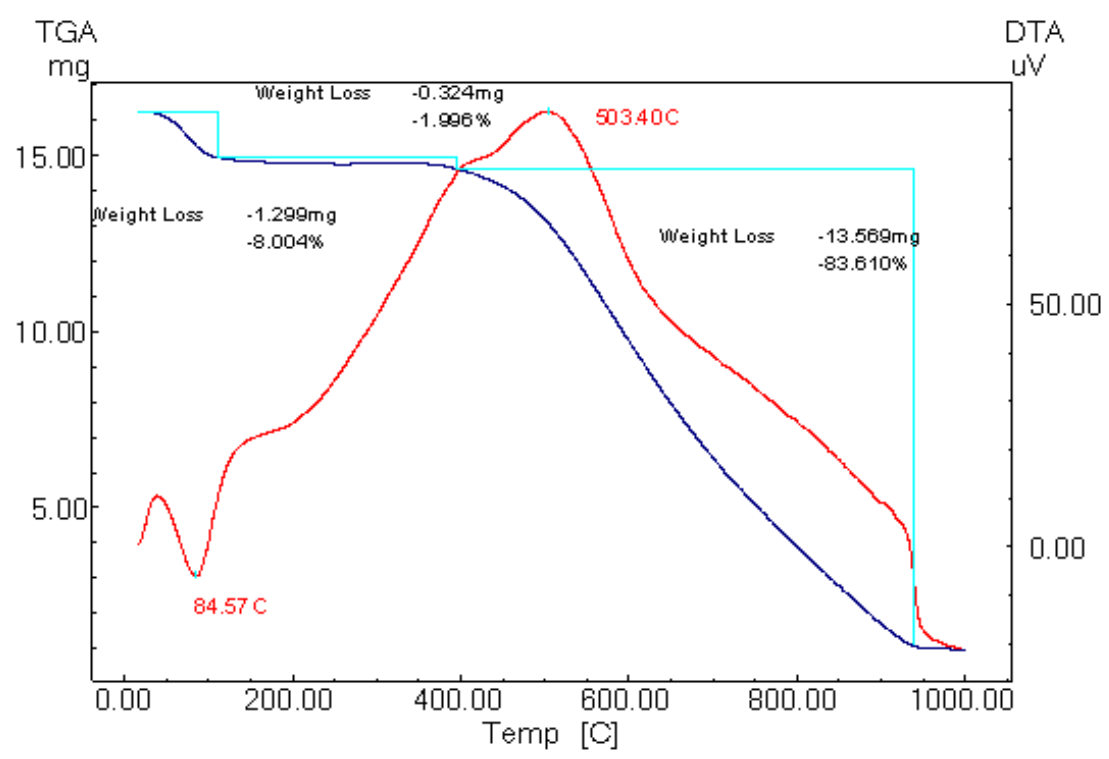

Figure 2. Thermogravimetric analysis (TG-DT) curves of MSAC.

\subsubsection{SEM}

Figure (3) displays the scanning electron microscopie (SEM) micrographs for particles of the prepared sorbent (MSAC) at two magnifications (1000x and 2000x). As can be seen from Figure (3), the low- magnification, micrographs (A) illustrate the irregular size and the varieties of pores in different widths. At the higher magnification, the micrographs (B) show shape of individual grains, irregular and heterogeneous surface morphology. 

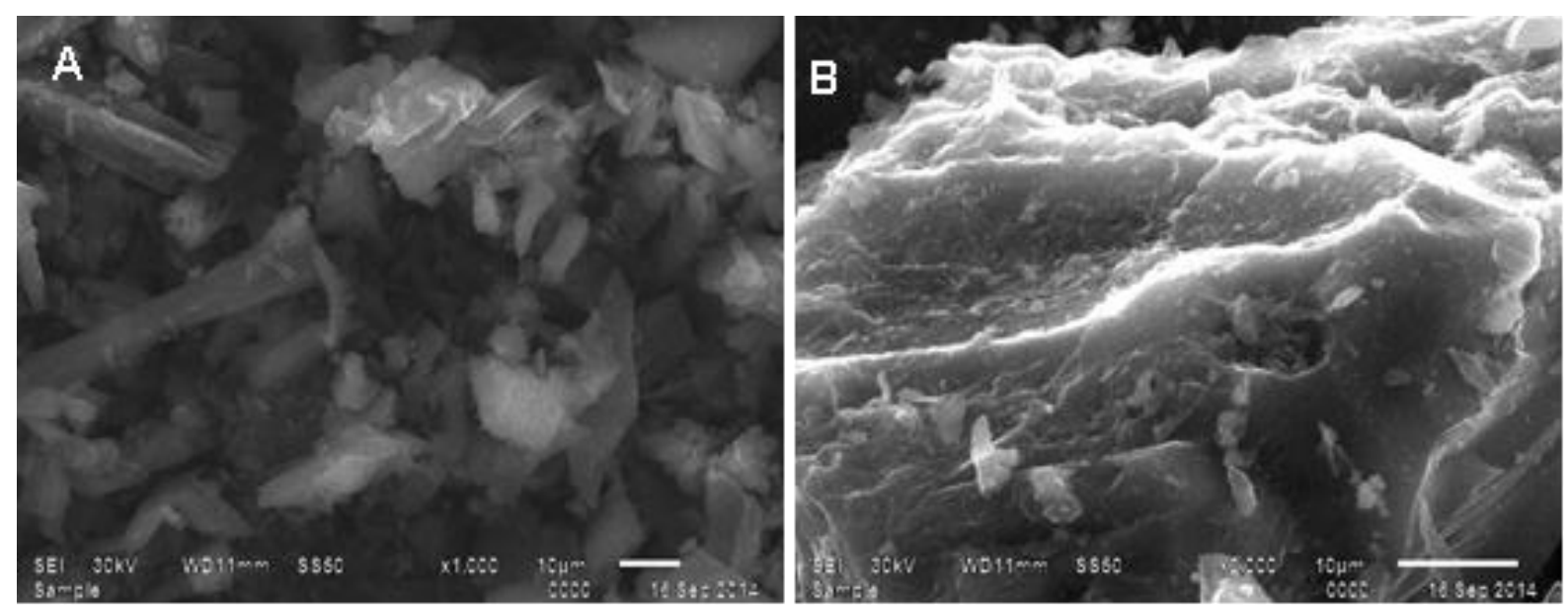

Figure 3. SEM analysis of MSAC. (A) Magnitude of 1000x; and (B) magnitude of $2000_{x}$.

\subsubsection{XRD}

The XRD spectrum of the powdered sample is shown in Figure (4), in which two peaks could be observed for the modified activated carbon. One peak between 15 and $35^{\circ} 2 \theta$, indicating the presence of amorphous silica, and the other is between 40 and $50^{\circ} 2 \theta$, corresponding to carbon. Similar results are reported by (Krishnarao,2001;Vieira et al.2012). Considering these angles and applying Bragg's law ( $n \lambda=2 d \sin \theta$ ) with $\lambda$ of $1.542 \AA$, $d$ values are obtained, which represent the basal interlayer distances. Modified activated carbon coconut shells sample exhibits the silica peak at incidence angles $(2 \theta)$ of 21.75 and 22.09, or values of basal interlayer distances of 4.08 and $4.02 \AA$, respectively (Vieira et al.2012). The carbon peak appears at incidence angles (20) between 44.25 and 44.30 corresponding to basal interlayer distances of 2.05 and $2.04 \AA$, respectively (Vieira et al.2012).

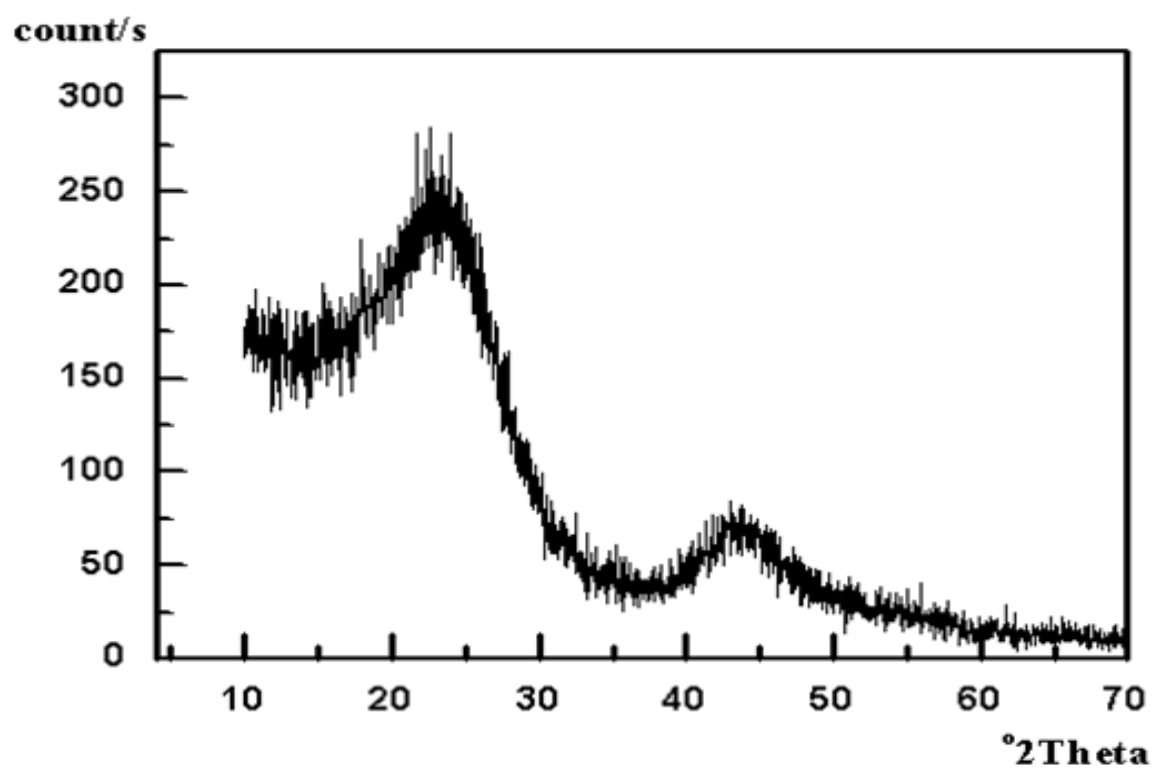

Figure 4. XRD diagrams of MSAC (as-prepared). 


\subsection{Adsorption dynamics}

\subsubsection{Effect of contact time}

Equilibrium time is one of the most important operational parameter for the effectiveness of treatment processes. In other words, this time represents the contact time at which the active sites and the sorbate are in contact to each other for the adsorption to occur. To as certain a suitable contact time between the studied sorbent and aqueous solutions, the fraction removal of $\mathrm{Eu}^{3+,} \mathrm{Ce}^{3+}$, $\mathrm{Sr}^{2+}$, and $\mathrm{Cs}^{+}$ions was studied as a function of time from 10 to 300 min while keeping other parameters constant as shown in Figure (5). It shows that the fraction removed significantly increases as the time is increased until equilibrium adsorption is established at $180 \mathrm{~min}$. This could be explained as being due to the fact that adsorption sites are well exposed, thus a quick reaction is occurred. It could be seen from figure(5) that the studied sorbent (MSAC) is efficient to remove more than 93.50, 87.50, 37, and 35.70\%, of $\mathrm{Eu}^{3+,} \mathrm{Ce}^{3+,} \mathrm{Sr}^{2+}$, and $\mathrm{Cs}^{+}$ions, respectively, at 180 min equilibrium time. This might be due to the nature of the sorbent and its available sorption sites which affect the time needed to reach equilibrium. Similar results are reported by (Bhattacharya et al .2008).. Fast adsorption in the beginning may be due to the availability of adsorption sites. The available sites in the sorbents tend to be reduced and hence the rate of adsorption is further decreased which attained a limiting value at equilibrium after the initial adsorption of adsorbate. Similar results are reported (Dahlan et al. 2013).. After $180 \mathrm{~min}$ of equilibrium time, there is no further significant removal observed. Thus, it is decided to assume the equilibrium time to be 180 min for the rest of this study.

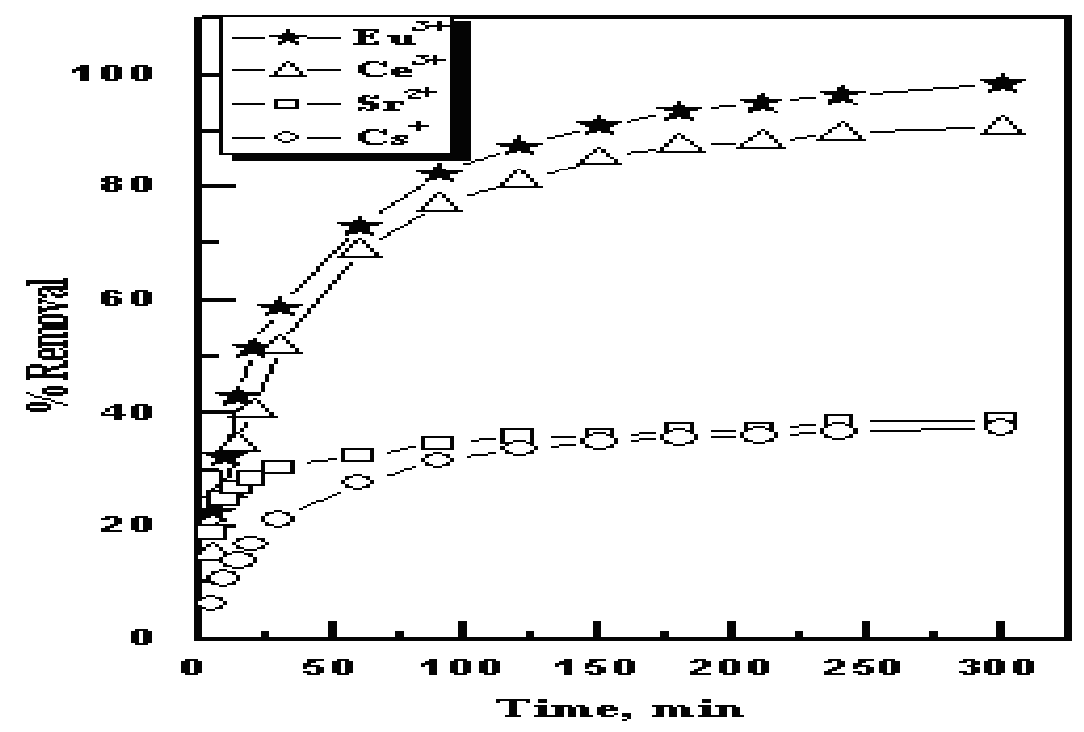

Figure 5. Effect of contact time on the removal of $\mathrm{Eu}^{3+}, \mathrm{Ce}^{3+}, \mathrm{Sr}^{2+}$ and $\mathrm{Cs}^{+}$by MSAC. 


\subsubsection{Effect of solution $\mathrm{pH}$}

The adsorption process is strongly governed by the solution $\mathrm{pH}$. The effect of $\mathrm{pH}$ solutions on the removal percentage of the investigated ions using MSAC is shown in Figure (6). It shows that the adsorption percentage increases with increasing the $\mathrm{pH}$ value of the solution for the studied metal ions. When the $\mathrm{pH}$ of the system increases, the number of negatively charged sites on the sorbent increases, due to an increase in the hydroxyl ion concentration as where the number of positively charged sites decreases. . Similar results are reported by (Iqbal, 2007). Therefore at higher pH, the surface of the sorbent gets more negatively charged by losing protons (deprotonation of different functional groups on the surface of the biosorbent) and thus favors the uptake of positively charged cations due to increased electrostatic force of attraction .Similar results are reported by (Ponnusam et al .2009)..

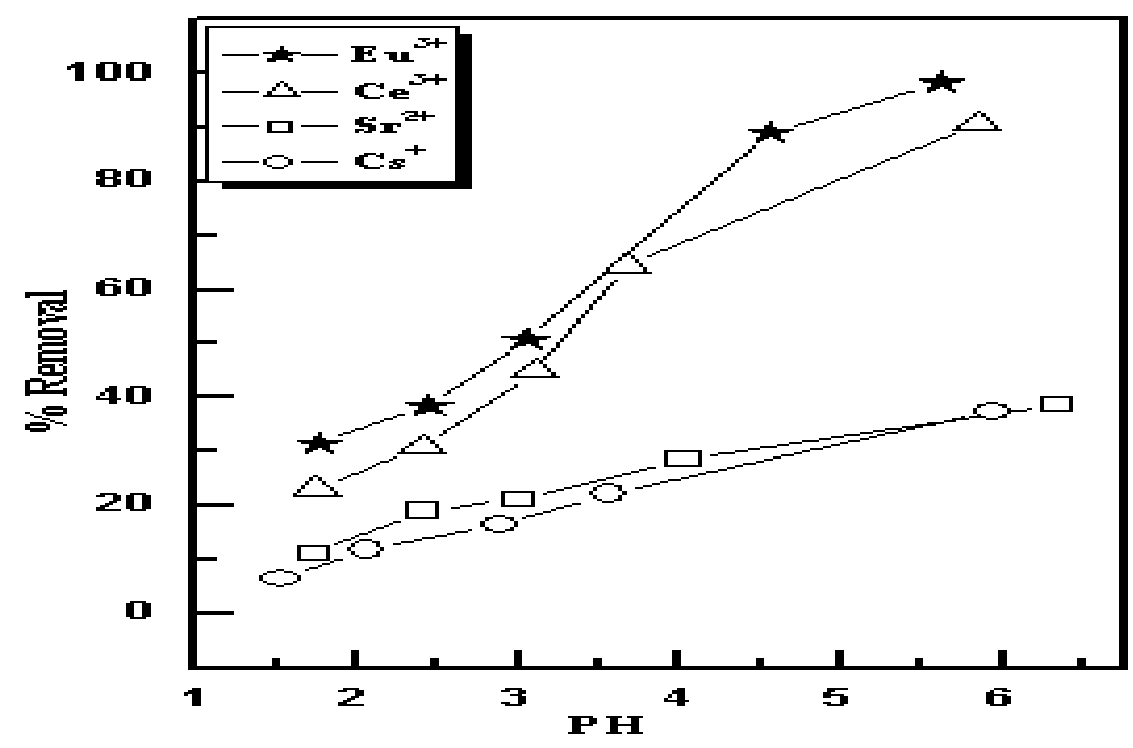

Figure 6. Effect of $\mathrm{pH}$ on the removal of $\mathrm{Eu}^{3+}, \mathrm{Ce}^{3+}, \mathrm{Sr}^{2+}$ and $\mathrm{Cs}^{+}$by MSAC.

\subsubsection{Effect of sorbent dosage}

The effect of a sorbent dosage on the removal of the studied ions is shown in Figure (7). The figure shows that the sorbent removal efficiency for the studied metal ions increases up to a certain limit where it remains almost constant at $0.05 \mathrm{~g}$ sorbent dosage and up. Hence, the optimum dosage from the modified activated carbon sample is found to be $0.05 \mathrm{~g} / 5 \mathrm{ml}$ (with $\mathrm{V} / \mathrm{m} 100 \mathrm{ml} / \mathrm{g}$ ) of $\mathrm{Eu}^{3+}$, $\mathrm{Ce}^{3+} \mathrm{Sr}^{2+}$, and $\mathrm{Cs}^{+}$solutions). The increase in the removal efficiencies with a sorbent dose can be attributed to availability of more adsorption sites. The rate of uptake increases with an increase in the sorbent dosage because it leads to a greater surface area for adsorption. Similar results are reported by (El-Sherif and Fathy, 2013).Since there is no significant change in the adsorption rate above $0.05 \mathrm{~g} / 5 \mathrm{ml}$, at initial concentration of $50 \mathrm{mg} / \mathrm{l}$, this amount is fixed and used for all the adsorption studies.

\subsubsection{Effect of initial metal concentration}

The effect of initial concentration of the studied metal ions on the removal efficiencies by the studied sorbent (MSAC) at the optimum dosage $(0.05 \mathrm{~g} / 5 \mathrm{ml})$ is shown in Figure (8). It can be 
concluded that the removal efficiency of the studied metal ions is decreased with an increase in the initial metal concentration from 50 to $400 \mathrm{mg} / \mathrm{l}$. This behavior may be due to an increase in the driving force which leading to increasing the collisions between metal ions and hence decrease the mobility of metal ions towards the adsorbent surface. (El-Sherif and Fathy, 2013). The results indicated that the adsorption of the investigated ions are much dependent on concentration of solution. These observations are in close agreement with that reported by (El-Sherif and Fathy, 2013).
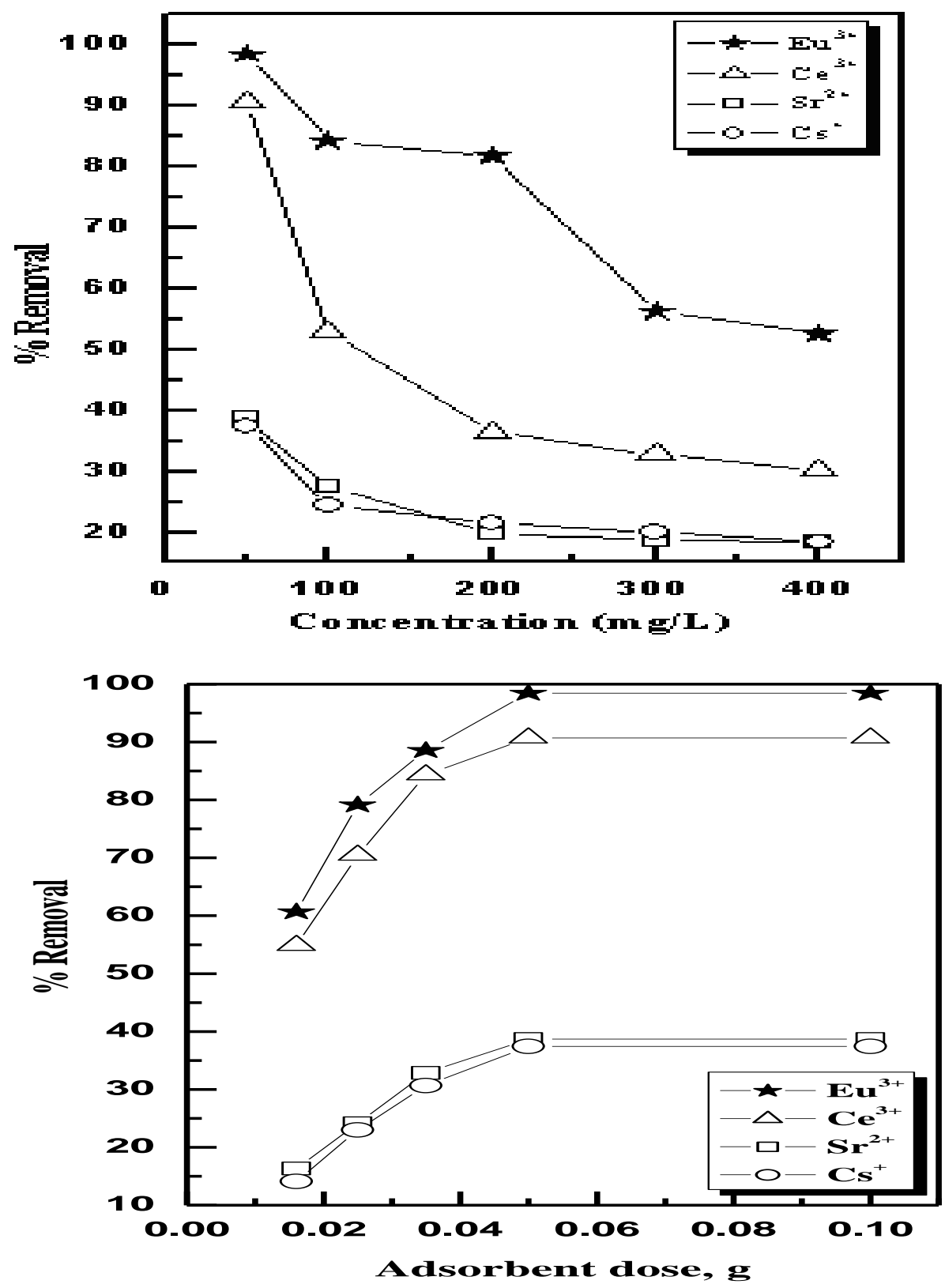

Figure 8. Effect of metal ions concentration on the removal of $\mathrm{Eu}^{3+}$, $\mathrm{Ce}^{3+}, \mathrm{Sr}^{2+}$ and $\mathrm{Cs}^{+}$by MSAC. 


\subsubsection{Effect of temperature}

To study the effect of temperature on the efficiency removal of $\mathrm{Eu}^{3+}, \mathrm{Ce}^{3+}, \mathrm{Sr}^{2+}$, and $\mathrm{Cs}^{+}$ions by MSAC, the experiments are carried out at temperatures varying from 25 to $65 \pm 1^{\circ} \mathrm{C}$,, as shown in Figure 9, it is observed that the removal efficiency for the studied metal ions is slightly increased with increasing temperature from 25 to $65 \pm 1^{\circ} \mathrm{Cfor}^{\mathrm{Eu}^{+3}}$ and, $\mathrm{Ce}^{+3}$, and sharp increased in case of $\mathrm{Sr}^{+2}$ and $\mathrm{Cs}^{+}$.This trend may be attributed to increasing kinetics energy of the sorbent metal ions, which increases the frequency of collisions between the sorbent and metal ions and thus enhances adsorption of metal ions on the surface of the sorbent. Similar results are reported by (Argunet al. 2007). As well as, creation of some new active sites on the adsorbent surfaces when the reaction temperature is increased. Similar results are reported by (El-Naggar et al .2010; El-Naggar et al 2014; Mishra et al .1996)

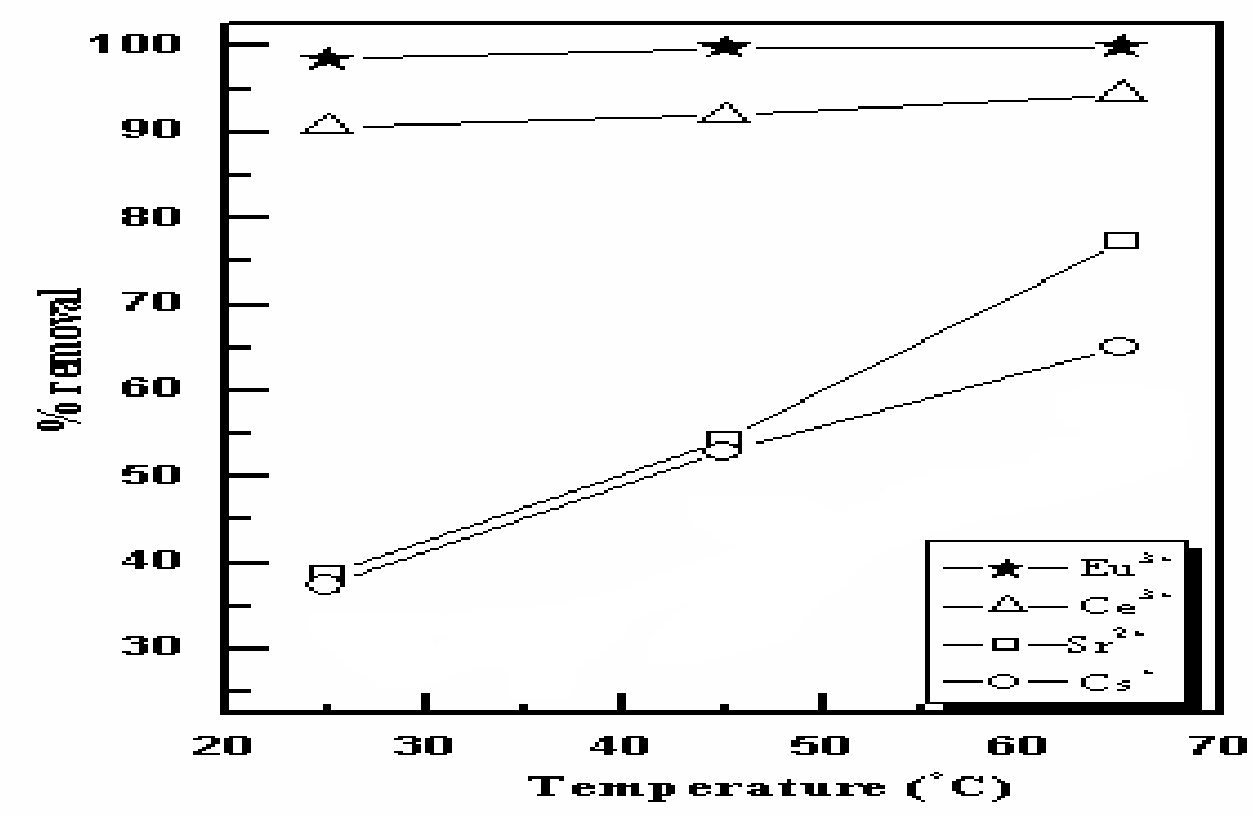

Figure 9. Effect of reaction temperature on the removal of $\mathrm{Eu}^{3+}, \mathrm{Ce}^{3+}$, $\mathrm{Sr}^{2+}$ and $\mathrm{Cs}^{+}$by MSAC.

\subsubsection{Effect of some interfering substances}

To study the effect of competing cations which may be present in radioactive waste such as $\mathrm{Na}^{+}$, also the effect of complexing agents as EDTA on the removal of $\mathrm{Eu}^{3+}, \mathrm{Ce}^{3+}, \mathrm{Sr}^{2+}$, and $\mathrm{Cs}^{+}$ions, the experiments are carried out at $\mathrm{Na}^{+}$and EDTA concentrations varying from $10^{-4}$ to $0.5 \mathrm{M}$. The results are presented in Table (4). It is shows that the sorption of $\mathrm{Eu}^{3+} \mathrm{Ce}^{3+}, \mathrm{Sr}^{2+}$, and $\mathrm{Cs}^{+}$ions is greatly affected as the concentration of EDTA is increased from $10^{-4}$ to $0.5 \mathrm{M}$. The data may indicate that the chelation of the studied metal ions with EDTA to form metal complex leading to a decrease in the free metal ions concentration in solution and hence decreasing the $\%$ sorption values. This effect is very obvious on increasing the concentration of competing agents. Similar results are reported by (Mishra et al .1996; Marsh et al .1995). 
On the other hand, The sorption of $\mathrm{Eu}^{3+} \mathrm{Ce}^{3+}, \mathrm{Sr}^{2+}$, and $\mathrm{Cs}^{+}$ions is slightly decreased with increasing the $\mathrm{Na}^{+}$ions concentrations as shown in Table(4). This poor effect of $\mathrm{Na}^{+}$compared to the effect of EDTA concentration may be due to either the lower electrostatic interaction of $\mathrm{Na}^{+}$ (monovalent) compared to the metal valences under study (Kotp,2008)or it may be related to the stereochemical factor (Inglezakis et al.2005). Finally, the sorption of $\mathrm{Eu}^{3+} \mathrm{Ce}^{3+}, \mathrm{Sr}^{2+}$, and $\mathrm{Cs}^{+}$ions is sharply decreased as the concentration of competing ions increased from( $10^{-4}$ to $\left.0.1 \mathrm{M}\right)$, and slightly decreased from (0.1to $0.5 \mathrm{M}$ ). Similar results are reported by (Inglezakis et al.2005)

Table 4. Effect of $\mathrm{NaCl}$ and EDTA concentrations on the $\%$ removal for $\mathrm{Eu}^{3+}, \mathrm{Ce}^{3+}, \mathrm{Sr}^{2+}$ and $\mathrm{Cs}^{+}$ions

\begin{tabular}{|c|c|c|c|c|c|c|c|c|c|c|c|c|c|}
\hline \multirow{4}{*}{$\begin{array}{c}\text { Cation } \\
\mathbf{s}\end{array}$} & \multicolumn{13}{|c|}{ \%of sorption removal in presence of the interfering substances } \\
\hline & \multirow[t]{3}{*}{0} & \multicolumn{2}{|c|}{$10^{-4}$} & \multicolumn{2}{|c|}{$10^{-3}$} & \multicolumn{2}{|c|}{0.01} & \multicolumn{2}{|c|}{0.1} & \multicolumn{2}{|c|}{0.25} & 0.5 & $(\mathrm{M})$ \\
\hline & & $\mathrm{NaCl}$ & EDT & $\mathrm{NaCl}$ & EDT & $\mathrm{NaCl}$ & EDT & $\mathrm{NaCl}$ & EDT & $\mathrm{NaCl}$ & EDT & $\mathrm{NaCl}$ & EDT \\
\hline & & & A & & A & & A & & A & & A & & A \\
\hline \multirow[t]{2}{*}{$\mathrm{Eu}^{3+}$} & 98.4 & 89.3 & 76.1 & 61.4 & 39.6 & 45.1 & 27.1 & 37.2 & 12.9 & 32.4 & 6.17 & 29.5 & 5.98 \\
\hline & 3 & 8 & 5 & 5 & 6 & 5 & 4 & 5 & 6 & 5 & & 5 & \\
\hline \multirow[t]{2}{*}{$\mathrm{Ce}^{3+}$} & 90.7 & 77.0 & 60.0 & 40.7 & 32.0 & 29.6 & 22.1 & 20.0 & 10.7 & 14.2 & 5.98 & 10.8 & 5 \\
\hline & 0 & 0 & 3 & 4 & 0 & 5 & 4 & 7 & 7 & 5 & & 6 & \\
\hline \multirow[t]{2}{*}{$\mathrm{Sr}^{2+}$} & 38.6 & 32.8 & 27.6 & 27.0 & 18.1 & 18.2 & 15.8 & 7.42 & 6.11 & 5.93 & 5.13 & 4.89 & 4.56 \\
\hline & 8 & 4 & 5 & 7 & 2 & 6 & 4 & & & & & & \\
\hline \multirow[t]{2}{*}{$\mathrm{Cs}^{+}$} & 37.4 & 19.2 & 15.1 & 12.6 & 8.33 & 6.86 & 5.80 & 2.62 & 2.11 & 2.02 & 2.00 & 2.00 & 1.85 \\
\hline & 0 & 1 & 1 & 9 & & & & & & & & & \\
\hline
\end{tabular}

\subsection{Capacity measurements}

\subsubsection{Saturation capacity}

The saturation capacity of the prepared sorbent (MSAC) $(\mathrm{mg} / \mathrm{g})$ for the studied metal ions are investigated by batch technique and the data are represented in Table (5).which Indicate that the affinity sequence for these cations is;

$$
\mathrm{Eu}^{3+}>\mathrm{Ce}^{3+}>\mathrm{Sr}^{2+}>\mathrm{Cs}^{+}
$$

This sequence is in accordance with the ionic radii of the sorbed metal ions which follow the order $\left(\mathrm{Eu}^{3+}<\mathrm{Ce}^{3+}<\mathrm{Sr}^{2+}<\mathrm{Cs}^{+}\right)$. The ions with smaller ionic radius are easily exchanged and move faster than the ions with greater ionic radius. 


\begin{tabular}{|c|c|c|c|}
\hline $\begin{array}{c}\text { Exchanging } \\
\text { ion }\end{array}$ & $\begin{array}{c}\mathrm{pH} \text { of the metal } \\
\text { solution }\end{array}$ & $\begin{array}{c}\text { Ionic } \\
\text { radii (Å) }\end{array}$ & $\begin{array}{c}\text { Capacity } \\
\text { (mq. g-1) }\end{array}$ \\
\hline $\mathrm{Eu}^{3+}$ & 4.47 & 0.95 & 163.84 \\
\hline $\mathrm{Ce}^{3+}$ & 4.64 & 1.07 & 85.55 \\
\hline $\mathrm{Sr}^{2+}$ & 4.03 & 1.18 & 69.85 \\
\hline $\mathrm{Cs}^{+}$ & 4.17 & 1.67 & 60.00 \\
\hline
\end{tabular}

Table 5. Saturation capacity of MSAC sorbent for the studied metal ions at agitating rate, 400

$\mathrm{rpm}$; initial metal concentration; $800 \mathrm{mg} / \mathrm{l}$ and temperature, $25 \pm 1^{\circ} \mathrm{C}$.

It is found that the studied sorbent MSAC has higher saturation capacity compared to other synthetic and natural sorbents. This may be due to its small pore diameters, which results in higher exposed surface area and hence high surface capacity for adsorption. Similar results are reported by ( Singh et al. 2013), in addition to the presence of multi-functional groups, such as carboxylic, hydroxyl, and lactone, which have a high affinity for metal ions .Similar results are reported by (Tan et al. 1993).

\subsubsection{Break-through capacity}

Investigations are conducted to explore suitable conditions for quantitative loading and sorption of the metals studied in neutral media $(\mathrm{pH}=5.56)$ by chromatographic column procedures at room temperature $\left(25 \pm 1^{\circ} \mathrm{C}\right)$. As far as the break-through capacity of the column is concerned, Figure( 11$)$ shows curves for $\mathrm{Eu}^{3+}, \mathrm{Ce}^{3+}, \mathrm{Sr}^{2+}$, and $\mathrm{Cs}^{+}$ions (100 $\mathrm{mg}^{-1}$ for each) obtained from the modified activated carbon column in the feed solutions. Each break-through curve reflects the percent concentrations of the respective metal ion in the effluent to the feed solution $\left(C / C_{0} \%\right)$ vs. effluent volume $(\mathrm{V} \mathrm{ml}$ ) as shown in the Figure. The corresponding uptake for the investigated cations per gram of solid is calculated using the following formula

\section{Breakthrough capacity $(\mathrm{mg} / \mathrm{g})=V_{(50 \%)} \times \frac{C_{0}}{m}$}

Where $Q_{0.5}$ means the break-through capacity in $\mathrm{g}, \mathrm{C}_{\mathrm{o}}$ is the initial metal concentration in $\mathrm{mg} / \mathrm{ml}, \mathrm{V}$ is the volume to break-through in $\mathrm{cm}^{3}$ and $\mathrm{m}$ is the weight of the dry sorbent in grams.

The values of breakthrough capacity under the conditions of the experiment can be easily estimated from Figure( 11 ) and calculated using equation( 4 ) they are found to be $3.00,14.80,17.80$ and $22.20 \mathrm{mg} \mathrm{g}^{-1}$ for $\mathrm{Eu}^{3+}, \mathrm{Ce}^{3+}, \mathrm{Sr}^{2+}$ and $\mathrm{Cs}^{+}$ions, respectively. It is also found that the selectivity of the ions towards the studied modified activated carbon is in the order: 


$$
\mathrm{Eu}^{3+}>\mathrm{Ce}^{3+}>\mathrm{Sr}^{2+}>\mathrm{Cs}^{+}
$$

This selectivity order is in accordance with that obtained from the batch technique. The breakthrough capacity for all the metal ions is low as compared to the saturation capacity for the same metal ions obtained from the batch technique due to the interference between ions.

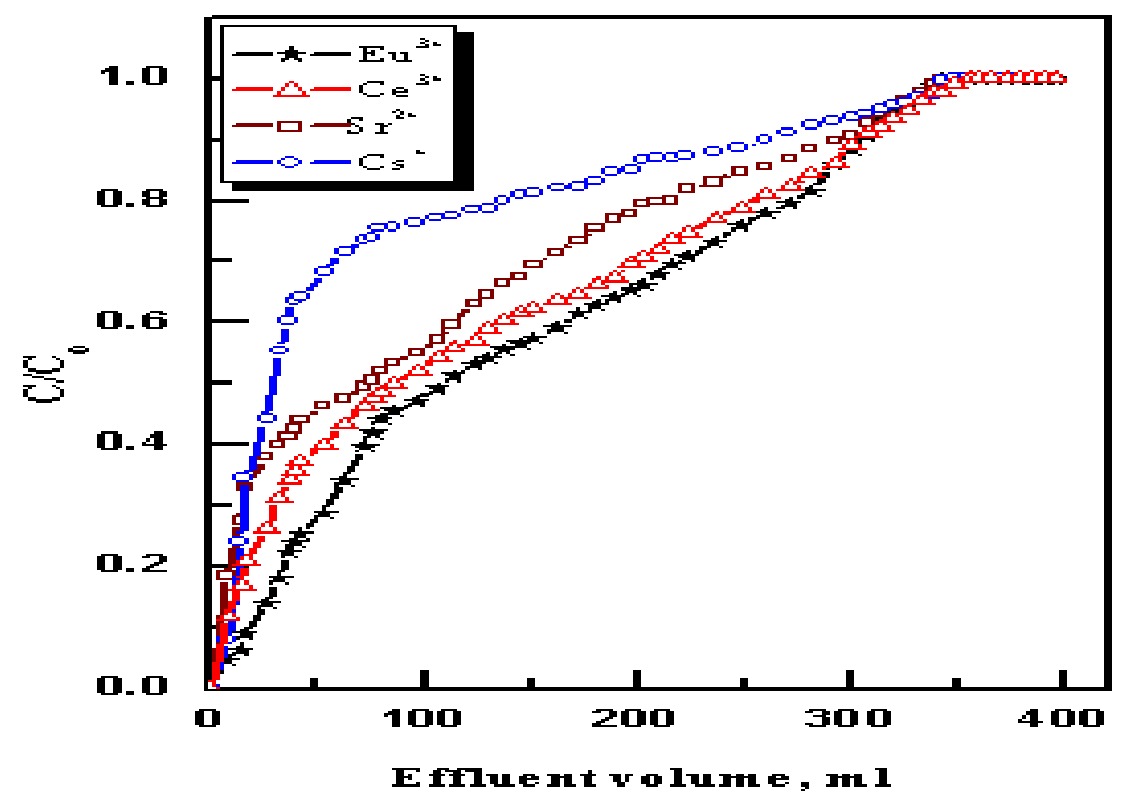

Figure 10. Break-throuhg curves of of $\mathrm{Eu}^{3+}, \mathrm{Ce}^{3+}, \mathrm{Sr}^{2+}$ and $\mathrm{Cs}^{+}$ions uptake by $\mathrm{MSAC}$ in $\mathrm{pH}=5.56$ and $25^{\circ} \mathrm{C}$

\subsection{Sorption thermodynamics}

The thermodynamic parameters, $\left(\Delta H^{\circ}\right)$ and $\left(\Delta S^{\circ}\right)$, are obtained from the following Van't Hoff equation:

$\operatorname{Ln} K_{d}=\frac{\Delta S^{o}}{R}-\frac{\Delta H^{o}}{R T}$

Where $\Delta S^{0}\left(\mathrm{~J} / \mathrm{mol} .{ }^{\circ} \mathrm{K}\right)$ is the standard entropy change, $\Delta \mathrm{H}^{\mathrm{o}}(\mathrm{kJ} / \mathrm{mol})$ is the standard enthalpy change, $\mathrm{R}$ is the gas constant $\left(8.314 \mathrm{~J} / \mathrm{mol} .{ }^{\circ} \mathrm{K}\right)$, and $\mathrm{T}$ is the absolute temperature $\left({ }^{\circ} \mathrm{K}\right)$. From Figure (12), $\Delta \mathrm{H}^{\mathrm{o}}$ and $\Delta \mathrm{S}^{\mathrm{o}}$ values are calculated from the slope $\left(-\Delta \mathrm{H}^{\mathrm{o}} / \mathrm{R}\right)$ and intercept $\left(\Delta \mathrm{S}^{\mathrm{O}} / \mathrm{R}\right)$ of the linear plot of $\ln K_{d}$ versus $1 / T$.

The thermodynamic parameter, $\left(\Delta G^{\circ}\right)$ is calculated using the relations:

$\Delta G^{o}=\Delta H^{o}-T \Delta S^{o}$

and

$\Delta G^{o}=-R T \ln K_{d}$

Where, $\Delta \mathrm{G}^{\circ}$ the standard free energy $(\mathrm{kJ} / \mathrm{mol})$. The $\Delta \mathrm{G}^{\circ}$ values of the studied metal ions sorbed on (MSAC) at 298,318 , and $338^{\circ} \mathrm{K}$ as well as $\Delta \mathrm{H}^{\circ}$ and the $\Delta \mathrm{S}^{\circ}$ values were presented in Table( 6). The positive values of $\Delta H^{\circ}$ indicate the endothermic nature of the adsorption process.similar 
results are reported by (El-Naggar et al.2010; El-Naggar et al .2014; El-Naggar et al .2014 ), while the positive values of $\Delta S^{\circ}$ for these elements are indication of the increased randomness at the solidsolution interface during the adsorption of these cations by the modified activated carbon(El-Naggar et al.2010; El-Naggar et al .2014; El-Naggar et al .2014 ). The negative values of the free energy change $\left(\Delta G^{\circ}\right)$, for the investigated metal ions"Table $6 "$ ", mean that the adsorption process is spontaneous and indicate the preferable adsorption of these cations on the studied sorbent as compared to $\mathrm{H}^{+}$ion (El-Naggar et al.2010; El-Naggar et al .2014; El-Naggar et al .2014 )

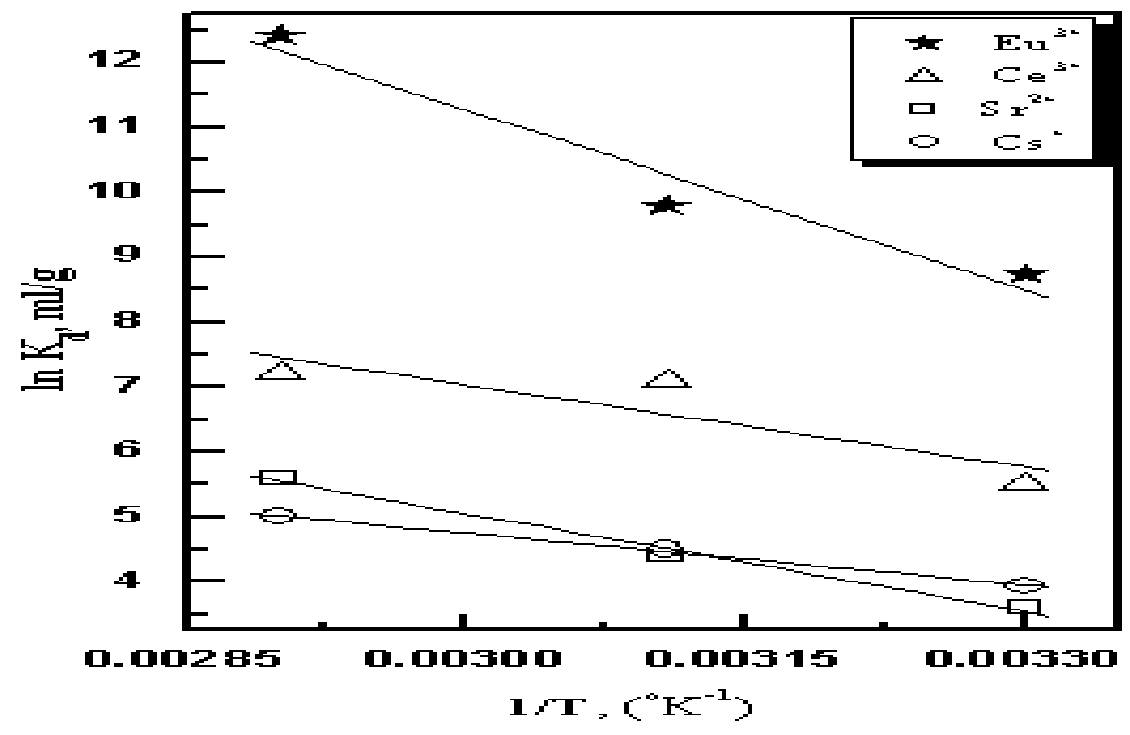

Figure 11. Van't Hoff plot of the adsorption of $\mathrm{Eu}^{3+}, \mathrm{Ce}^{3+}, \mathrm{Sr}^{2+}$ and $\mathrm{Cs}^{+}$ions by MSAC.

Table 6: Thermodynamic parameters for adsorption of $\mathrm{Eu}^{3+}, \mathrm{Ce}^{3+}, \mathrm{Sr}^{2+}$ and $\mathrm{Cs}^{+}$ions by MSAC.

\begin{tabular}{|c|c|c|c|c|}
\hline Metal ion & Temp., (K) & $\Delta \mathrm{H}^{\circ},\left(\mathrm{KJ} \mathrm{mol}^{-1}\right)$ & $\Delta \mathrm{G}^{\mathrm{o}},\left(\mathrm{KJ} \mathrm{mol}^{-1}\right)$ & $\Delta \mathrm{S}^{0},\left(\mathrm{~J} \mathrm{~mol}^{-1} \mathrm{~K}^{-1}\right)$ \\
\hline $\mathrm{Eu}^{3+}$ & 298 & 76.85 & -21.65 & 324.25 \\
\hline $\mathrm{Ce}^{3+}$ & 298 & 35.08 & -16.64 & 163.70 \\
\hline $\mathrm{Sr}^{2+}$ & 298 & 41.65 & -8.92 & 166.86 \\
\hline $\mathrm{Cs}^{+}$ & 298 & 22.20 & -79.36 & 106.08 \\
\hline
\end{tabular}




\section{CONCLUSIONS}

- $\quad$ The produced modified surface activated carbon is characterized using X-ray (XRD and XRF), CHN elemental analysis, ICP , FTIR, TGA-DTA and scanning electron microscopy (SEM).

- The solubility experiments indicate that the produced sorbent is resistant to $\mathrm{HNO}_{3}$ and $\mathrm{HCl}$ media

- The obtained data, reveal that the modified surface activated carbon produced from coconut shell is a good adsorbent for the removal of $\mathrm{Eu}^{3+}, \mathrm{Ce}^{3+}, \mathrm{Sr}^{2+}$ and $\mathrm{Cs}^{+}$ions from radioactive waste solutions.

- . The removal efficiency of the studied metal ions is controlled by solution $\mathrm{pH}$, contact time, adsorbent dose, adsorption temperature, initial ion concentrations, and interfering ions such as sodium chloride salt and ethylenediaminetetraacetic acid (EDTA).

- The studied sorbent has high saturation and break-through capacities as compared to other synthetic and natural sorbents

- The adsorption process is spontaneous and endothermic in nature which is further confirmed by the determined of thermodynamic parameters.

- Coconut shell (a waste) is inexpensive and readily available. Thus this study provides a cost effective means for removing metal ions from contaminated water or effluents.

\section{REFERENCES}

Abdalla S., Moloukhia H. Potential use of oxidized animal charcoal and snail ash in treatment of aqueous waste solutions containing europium ions, Arab J. Nucl. Sci. App, 39 (3) 12(2006).

Abdel-Rahman R.O., El Kamash A.M. , Ali H.F., Hung Y.T. Overview on recent trends and developments in radioactive liquid waste treatment part 1: Sorption/Ion Exchange Technique. Int. J. Environ. Eng. Sci., 2 (1)16(2011). 
Al-Degs Y.S., El-Barghouthi M.I., Issa A.A., Khraisheh M.A., Walker G.M., "Sorption of Zn(II), Pb(II), and Co(II) using natural sorbents: Equilibrium and kinetic studies", Water Research, 40 2645- 2658(2006).

Amuda O.S. , Amoo I.A., Hung Y., "Radioactive Element Removal from Contaminated Groundwater by Agricultural Waste-Based Activated Carbon", International Journal of Water Resources and Arid Environments 1(1) 71-82(2011).

Argun M.E., Dursun S., Ozdemir C., Karatas M., "Heavy metal adsorption by modified oak sawdust: Thermodynamics and kinetics", Journal of Hazardous Materials 141 77-85(2007).

Awwad N.S., El-Afifi E.M., El-Reefy S.," Solvent extraction of Uranium(VI) by CYANEX 301/CYANEX 921and their Binary mixture from aqueous $\mathrm{HNO}_{3}$ and $\mathrm{H}_{2} \mathrm{SO}_{4}$ media", Arab J. Nucl.Sci.\&Appl.,37(3) 108(2005).

Bhattacharya A.K., Naiya T.K., Mandal S.N. , Das S.K.," Adsorption, kinetics and equilibrium studies on removal of $\mathrm{Cr}(\mathrm{VI})$ from aqueous solutions using different low-cost adsorbents". Chem. Eng. J., 137(3) 529-541(2008).

Clark A., "Theory of Adsorption and Catalysis", Academic Press, New York, (1970).

Dahlan I., Hassan S.R., Hakim M.L., "Removal of iron (Fe ${ }^{2+}$ ) from aqueous solutions using siliceous waste sorbent", Sustain. Environ. Res., 23(1) 41-48(2013).

Daifullah A.A.M ., Moloukhia H, , "Removal of cobalt and Europium Radioisotopes using Activated carbon prepared from Apricot stones,isotope"\& RAD.RES.,34,2,271-283(2002).

I-Aryan Y.F., , El-Said H., Abdel-Galil E.A.," Synthesis and characterization of polyaniline-titanium tungsto phosphate; its analytical applications for sorption of $\mathrm{Cs}^{+}, \mathrm{Co}^{2+}$ and $\mathrm{Eu}^{3+}$ from radioactive waste solutions", Radiochemistry, 56 (6)

614-621(2014)

El-Naggar I.M., Hebash K.A., Sheneshen E.S., Abdel-Galil, E.A., "Preparation, characterization and ionexchange properties of a new 'organic-inorganic' composite cation exchanger polyaniline silicotitanate: its applications for treatment of hazardous metal ions from waste solutions", Inorganic Chemistry An Indian Journal, 9 (1) 1-14(2014).

El-Naggar I.M., Mowafy, E.A. Abdel-Galil E.A., El-Shahat M.F., "Synthesis, characterization and ionexchange properties of a novel 'organic-inorganic' hybrid cation-exchanger: polyacrylamide Sn(IV) molybdophosphate", Global Journal of Physical Chemistry, 1 (1) 91-106(2010).

El-Naggar I.M., Zakaria, E.S., Abou-Mesalam, M.M. Aly H.F., "Removal of some radioactive nuclides by in-situ precipitation with ion exchange" Czechoslova, J. of Physics, 49 951-958(1999).

El-Naggar M.R., El-Dessouky M., Elkamash, A. Ghoneem A., Kinetic studies on the removal of cesium and strontium ions from aqueous solution using prepared zeolite- A, Arab J. Nulc.Sci.\&Appl.,37(2) 92(2005). 
El-Naggar, I.M., Zakaria E.S., El-Kenany W.M., El Shahat, M.F. " Synthesis and equilibrium studies of titanium vanadate and its use in the removal of some hazardous elements", Radiochemistry, 56 (1) 86-91(2014).

El-Sherif I.Y., Fathy N.A.," Modification of Adsorptive Properties of Bagasse Fly Ash for Uptaking Cadmium from Aqueous Solution", Environmental Research, Engineering and Management, 2 (64) 19-28(2013).

Hassan W., Farooq U., Ahmad M., Athar M., Ain Khan M., "Potential biosorbent, Haloxylon recurvum plant stems, for the removal of methylene blue dye", Arabian Journal of Chemistry, Article in press (2013).

Ibrahim D.M., El-Hemaly, S.A., Abdel-Kerim F.M., "Study of rice-husk ash silica by infrared spectroscopy", Thermochimica Acta, 37 (3) 307-314(1980).

Inglezakis V.J., Zorpas A.A., Loidzidou, M.D. Grigoropoulou H.P.," The effect of competitive cations and anions on ion exchange of heavy metals", Sep. \& purification Technol., 46 (3) 202-207(2005).

International Atomic Energy Agency. Standardization of Radioactive Waste Categories; TRS No. 101; IAEA: Vienna, Austria, (1970)

Iqbal M.J., N. A.M., "Adsorption of dyes from aqueous solutions on activated charcoal"I. J. Hazard. Mater. B139, 57-66(2007).

Jantzen-carolm, Disposal of tank $48 \mathrm{H}$ organics by fluidized bed stream reforming. Funding Organization, united states, 29(2004).

Kobya M., Demirbas E., Senturk, E. Ince M.," Adsorption of heavy metal ions from aqueous solutions by activated carbon prepared from apricot stone", Bioresource Technology 96 1518-1521(2005).

Kotp Y.H., "Removal of some heavy elements using new synthesized inorganic ion exchange materials", M.Sc. thesis, Chemistry Department, Faculty of Science, Al-Azhar University (Girls), (2008).

Krishnarao, R.V. Subrahmanyam J., Kumar T.J., "Studies on the formation of black particles in rice husk silica ash". J. Eur. Ceram. Soc., 21 99-104(2001).

Marsh S.F., Report LA-12943, Los Alomes National Lab., Los Alomes, New York, Mexico, April (1995).

Mishra S.P., Singh U.K., Tiwari D.," Inorganic particulates in removal of toxic heavy metal ions", J. Radiation. Chem., 207- 210(1996).

Moloukhia H., Abdel Raouf, R.W. El-Khalafawy, A. Removal of strontium from aqueous solutions using unconventional biomass materials, Arab J. Nucl. Sci. App, 39 (2) 72(2006).

Moreno-Castilla C., Lopez-Ramon M.V., Carrasco-Marin, F.," Changes in surface chemistry of activated carbon by wet oxidation", Carbon, 38 (14) (2000), (1995)-(2001). 
Nandal M., Hooda R., and Dhania G.," Tea Wastes as a Sorbent for Removal of ,Technology," 4 (1) 243-247(2014).

Nowier H.G., Metwally S.S., Abd El-Rehim S.S., Aly H.F., "Extraction of trivalent La, .Na and Eu from nitric acid solution by ionquest-801 loaded on Lewatit CA 9221", Arab J. Nulc.Sci.\&Appl.,39(3) 38(2005).

Omar H.A., Moloukhia H.,"use of activated carbon in removal of some Radioisotopes from their waste solutions". Jouranal of Hazardous Materials.157,242-246(2008).

Padhi B.K., Patnaikb C., "Development of $\mathrm{Si}_{2} \mathrm{~N}_{2} \mathrm{O}, \mathrm{Si}_{3} \mathrm{~N}_{4}$ and $\mathrm{SiC}$ Ceramic Materials Using Rice Husk", Ceramics Int., 21 213-220(1995)

Ponnusam V. i, Gunasekar V., Srivastava S.N.," Kinetics of methylene blue removal from aqueous solution using gulmohar (Delonix regia) plant leaf powder: multivariate regression analysis". J. Hazard. Mater. 169 119-127(2009).

Pradhan B.K., Sandles N.K., "Effect of different oxidizing agent treatments on the surface properties of activated carbons", Carbon, 37 (8) 1323-13321(999).

Rao C.N.R.," Chemical Applications of Infrared Spectroscopy", Academic Press, New York, 355(1963).

Singh U., Kaushal R. K.," Treatment of Waste water with Low Cost sorbent - A review) VSRD International Journal of Technical \& Non-Technical Research, 4 (3) 33-42(2013).

Stuart B., "Modern Infrared Spectroscopy", John Willy \& Sons, New York (1996).

Tan W.T., Ooi S.T., Lee C.K., "Removal of chromium (VI) from solution by coconut husk and palm pressed fibers", Environ. Technol. 14 (3) 277-282(1993).

Vieira M.G.A., de Almeida Neto A.F., Carlos da Silva M.G., . Nóbrega C.C, Melo Filho A.A.," Characterization and use of in natura and calcined rice husks for biosorption of heavy metals ions from aqueous effluents", Brazilian Journal of Chemical Engineering, 29 (03) 619-633(2012). 


\section{ملخص العربيى}

التخلص من أيونات الأيروبيوم و السيريوم و الأسترونثيوم و السيزيوم من المحاليل المشعة السائلة بإستخدام الكربون المُنشط المُعل السطح المُحضر من قشرة ثمرة جوز الهند

حنان كامل ملوخيه ا ، .وفاء صلاح حجازي ب، عزت عبدد القادر عبد الجليل ا، ساره سيد محمد محروس

1. قسم الكيمياء الاشعاعيه -هيئه الطاقه الذريه ،

\section{Y. قسم الكيمياء كلية البنات}

فى هذا البحث تم تحويل قثرة ثمرة جوز الهند و هى أحد المخلفات الزراعية الى منتج عالى الجودة هو الكربون المُنشط المُعدل السطح بالتنشيط الكيميائى بإستخدام حمض النيتريك و فوق أكسيد الهيدروجين .

وتم إستخدامه لتقليل تركيز أيونات كل من الإيروبيوم و السيريوم و الأسترونثيوم و السيزيوم فى المحاليل السائلة الإشعاعية الأخُلقة . فى هذا البحث تم التعرف على خصائص الكربون الفيزيائية و الكيميائية

بأساليب متنوعه مثل زمن الأتزان و تركيز أيون الهيدروجين و وزن المادة الماصة المستخدمة و أيضا دراسة نركيز الأيونات بالمحلول وكذلك تم دراسة تأثير وجود بعض الأيونات المنافسة فى المحلول و كذلك وجود بعض المتر اكبات العضوية على عملية الأمتصاص .كما تم أيضا دراسة عوامل الديناميكية الحرارية ـ وقد أثتتت التجارب أن المنتج له ثبات كيميائى عالى و أن • 11 دقيقة رج للمحلول مع المادة الماصة كافية للوصول لزمن الأتزان ـ و كانت نسب ألامتصاص

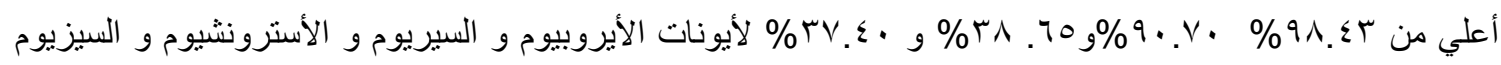
على التو الى .

هذا البحث له أهمية تطبيقية و أكاديمية فى تقليل تركيز أيونات كل من الإيروبيوم و السيزيوم و الأسترونشيوم و السيريوم فى المحاليل المشعة السائلة بإستخدام مواد رخيصة و متو افرة محليا من مخلفات زر اعية سهل الحصول عليها دون أدنى تكلفة. 